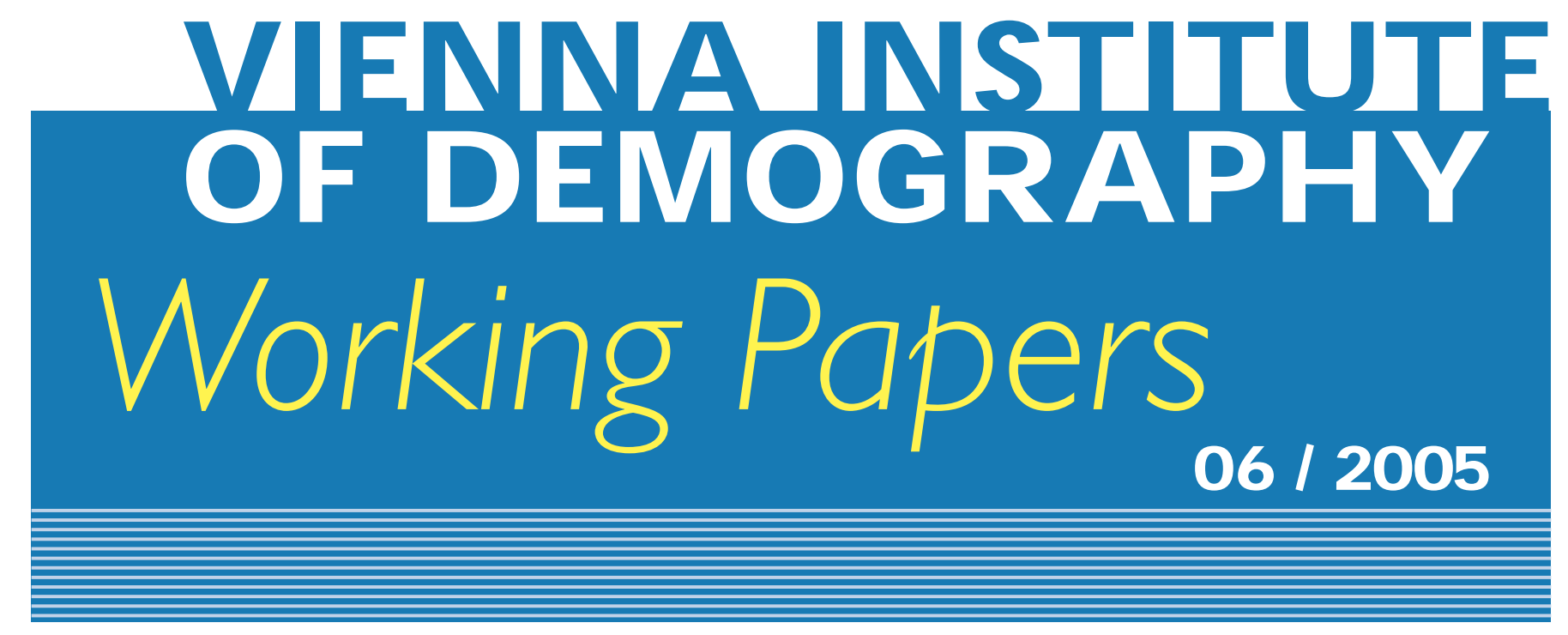

Kim, Jungho, H enriette Engelhardt, Alexia Prskawetz, and Arnstein Aassve

\title{
Does Fertility Decrease the Welfare of H ouseholds? An Analysis of Poverty Dynamics and Fertility in Indonesia
}

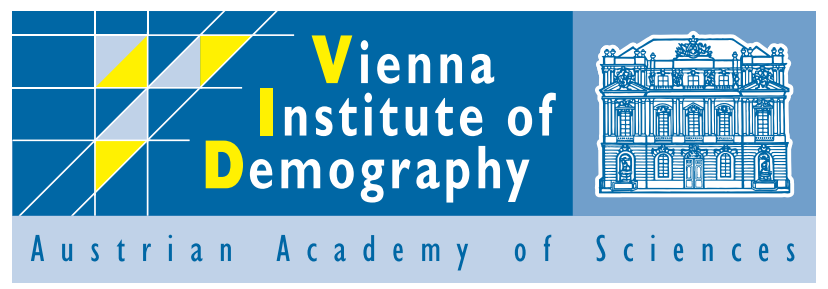

Vienna Institute of D emography Austrian A cademy of Sciences

Prinz Eugen-Straße 8-10 · A-1040 Vienna · A ustria

E-Mail: vid@ oeaw.ac.at

W ebsite: www.oeaw.ac.at/vid 


\begin{abstract}
It is generally accepted that lower population growth is associated with positive economic development. Although there is a large body of literature supporting this hypothesis at the macro level, few studies have analyzed the causal effect of fertility on household welfare at the micro level. In this paper we present an empirical analysis of the relationship between household welfare and fertility for Indonesia - a country which has experienced unprecedented economic growth and sharp fertility declines over recent decades. The focus of our paper is twofold: First, we introduce and apply propensity score matching methods to study the relationship between fertility outcomes and economic variables at the household level. Secondly, we explicitly test for the sensitivity of our results with respect to alternative measures of welfare at the household level. When consumption expenditure per person is used as a measure of welfare, the analysis suggests that the correlation between fertility and household welfare is sensitive to the choice of the parameters governing economics of scale and equivalence scales at the household level. The lower these values are the less likely will an additional child depress household welfare. On the other hand, when the share of food in total expenditure is used as a measure of welfare, the result does not produce a decisive sign of the correlation between fertility and household welfare.
\end{abstract}

\title{
Keywords
}

Poverty Dynamics, Fertility, Welfare, Household Size, and Indonesia.

JEL Classification Number: O12, J10.

\section{Authors}

Jungho Kim is a Junior Researcher at Vienna Institute of Demography, Austrian Academy of Sciences, Austria. Mailing Address: Vienna Institute of Demography, Prinz Eugen Strasse 8, 2nd floor, 1040 Wien, Austria. E-mail: jungho.kim@oeaw.ac.at. Phone: +43 1-515-81-7702. Fax: +43 1-515-81-7730.

Henriette Engelhardt is a Senior Researcher at Vienna Institute of Demography.

Alexia Prskawetz is a Senior Researcher at Vienna Institute of Demography.

Arnstein Aaassve is a Chief Research Officer at Institute for Social and Economic Research of University of Essex, U.K.

\section{Acknowledgements}

The project is funded by the Austrian Science Foundation (Contract No. P16903-605). 


\title{
Does Fertility Decrease the Welfare of Households? An Analysis of Poverty Dynamics and Fertility in Indonesia
}

\author{
Jungho Kim, Henriette Engelhardt, Alexia Prskawetz and Arnstein Aaassve
}

\section{Introduction}

In many developing countries we observe that fertility declines often come along with reductions in poverty. Indonesia is perhaps the most striking example of this pattern. Over the last four decades Indonesia has experienced unprecedented economic growth together with a dramatic fertility decline. Table 1 shows that GDP per person increased by more than 12 times over the period 1970 to 1995, and total fertility rate fell by around 50 percent over the same period. This dynamic nature of the socio-economic change combined with a large population and its vast geographical diversity has attracted considerable interest among economists and policy makers alike. However, the majority of studies has focussed on the relationship from a macro level perspective, and most of the empirical anlaysis is based on aggregate data sources.

However, the correlation between fertility and poverty development found at the country and household level does not provide inside into the causality between the demographic and economic processes (Mason \& Lee 2004, Birdsall et al. 2001). From previous studies (McNicoll 1997, Schoumaker \& Tabutin 1999) we know that the relation between poverty and fertility is not unidirectional but dependent on the stage of economic development. While in most contemporary developing countries this relationship is positive, a negative relationship has been reported within the very poorest countries. The latter results are associated with lower reproduction capability and higher rates of infertility among poor households (Lipton 1998 and Livi-Bacci \& di Santis 1998). Clearly many factors that influence fertility also determine wellbeing. These include education, health services and family planning policies. In addition to joint causation, reverse causation may also take place. Among poor households the demand for children is high since those households rely on their children's labor supply and often the child's support for old age is a further factor increasing the demand for children. Higher fertility in turn is associated with less educational investment (i.e. demand for quantity rather than quality of children) and consequently lower earnings potential for children fostering intergenerational transmission of poverty (Moav 2005).

Empirical studies that tried to identify the causal relationship between fertility and poverty have so far relied on aggregate level data and cross-sectional micro level data (cf. the review by Merrick 2001). With these data, it is difficult to provide robust causal information about fertility and well-being due to the fact that fertility and household income are jointly determined. Recent longitudinal household surveys in developing countries that include the timing of fertility together with information on consumption expenditures, income and other measures of well-being allow to identify the dynamic relation between poverty and fertility. So far, these data sets have not been applied to study the link between poverty and fertility. 


\section{Table 1: Total Fertility Rate (TFR) and Gross Domestic Product (GDP) per capita in Indonesia}

\begin{tabular}{crr}
\hline \hline Period & TFR & GDP per capita \\
\hline $1965-1970$ & 5.57 & 80.3 \\
$1970-1975$ & 5.20 & 237.0 \\
$1975-1980$ & 4.73 & 516.8 \\
$1980-1985$ & 4.11 & 521.2 \\
$1985-1990$ & 3.50 & 625.9 \\
$1990-1995$ & 3.00 & $1,023.6$ \\
\hline \hline
\end{tabular}

Notes: i) Source of TFR: World Population Prospects: The 2000 Revision, Vol. I, United Nations Population Division (requoted from World Resources Institute)

ii) Source of GDP per capita: World Development Indicators 1999, World Population 1950-2050 (The 1998 Revision), The World Bank, United Nations Population Division.

iii) GDP per capita is in current US dollars, and indicates the value in the last year of each period.

The main complication in this literature is the issue of measuring a variation of fertility that is exogenous with respect to wellbeing. Two approaches have been adopted in estimating the effect of fertility on female labor supply in the literature. The first is to use a natural experiment like twins or sex composition of the first two children as instrumental variables for fertility (e.g. Rosenzweig \& Wolpin 1980; Angrist \& Evans 1998). Although these instruments are reasonably valid, Rosenzweig \& Wolpin (2000) note that this approach requires some restrictions on the utility function (e.g. the separability of leisure and consumption, etc.). The second approach is to use the residual in a fertility regression as a measure of unobserved fecundity (Rosenzweig \& Schultz 1985). Measuring female fecundity is certainly a useful approach, but the result is less intuitive. As an alternative approach, we apply a matching method in order to estimate the effect of an additional child on welfare of household members in the short run. The econometric method that we apply relies on a quasi-experimental approach, i.e. an experiment without randomization. In principle we identify fertility, i.e. the birth of a child, as the treatment and household welfare as the outcome variable (see Mattei (2004) for a similar approach). Our results on the effect of fertility on household welfare may nevertheless be sensitive to the measure of welfare. Hence, a second focus of our paper is to test the sensitivity of the correlation between fertility and household welfare with respect to two alternative measures of welfare. These are household real expenditure per person and expenditure share of food.

A further difficulty in establishing a causal relationship between fertility and poverty is related to the measure of poverty (Ravallion 1996). It is not clear to what extent the results are influenced by the way wellbeing is measured. As argued in Lanjouw \& Ravallion (1995) "Despite extensive work on welfare measurement in economics, there is still no preferred method for making inter-personal comparisons across households of different size and/or composition". For instance, a common measure on wellbeing at the household level is expenditure per adult equivalent. However, the choice of equivalence scales that is related to the assumption on intra-household resource allocation between children and adults, is not straightforward and may differ across countries, regions and cultures. Assigning equal weight to all household members and ignoring economics of scales with household size results in the commonly used measure of per capita household expenditure which ignores the compositional and size effect of households on the measure of wellbeing. As shown in Lanjouw \& Ravallion (1995) for Pakistan, the measure of poverty is sensitive to the size elasticity assumed. In this 
paper we go one step further and consider whether the causal relation between fertility and poverty is sensitive to the weight on a child's consumption relative to an adult's as well as the economy of scale.

The rest of the paper is organized as the following. In section 2 we describe the data and variables used in our study. The measure of household welfare and estimates of the equivalence scale implied by our data are summarized in section 3 . The method of analysis is discussed in section 4 . The results on whether and in which direction fertility causes wellbeing are summarized in section 5. In the first part, we apply household consumption expenditure per person and investigate the sensitivity of the results depending on the way in which household size and household composition is taken care of. In the second part, we apply the food share of household expenditure as a measure of welfare. In section 6 we conclude.

\section{Data and Variables}

\subsection{Data}

Our study is based on the data from the Indonesian Family and Life Survey (IFLS). The IFLS consists of three waves in total, IFLS1 conducted in 1993/94, IFLS2 and IFLS2+ in 1997 and 1998, and IFLS3 in 2000. In 1997 Indoenesian economy was hit by the Asian financial crisis. The second wave of the IFLS was conducted shortly before the event. Thus we do not use any of the waves after 1997 in order to avoid estimates being driven by the onset of the financial crisis. The IFLS is of exceptional quality and is ideal for the purpose of constructing a quasi experiment of the type implemented here, as the survey contains extensive questionnaires on a range of aspects of household economy covering a period of steady economic growth. The survey has been conducted by RAND Corporation in collaboration with UCLA and Lembaga Demografi, University of Indonesia. The sample is representative of about 83 percent of the Indonesian population and contains over 30,000 individuals living in 13 of the 27 provinces in the country. IFLS1 has 7,224 households, and subsequent waves targeted all the splitoff households as well as all the original households previously interviewed. The response rate for the IFLS2 was 94 percent of the original sample. The survey contains a wealth of information collected at the individual and household level, including multiple indicators of economic well being such as consumption, income, and assets. It also includes information on education, migration, labor market outcomes, marriage, fertility, contraceptive use and health. Information on relationships among co-residents and non-co-resident family members and inter-generational mobility are included as well. Another outstanding feature of the IFLS is the quality of information provided at the community level. The panel has information concerning the physical and social environment, infrastructure, employment opportunities, food prices, access to health and educational facilities, and the quality and prices of services available at those facilities.

\subsection{Control Variables}

Our unit of analysis is the household. There are 6,742 households that were interviewed in both waves. After dropping observations that have missing values for relevant variables, the final sample consists of 4,852 households. Table 2 presents the summary statistics of household characteristics. The proportion of households with urban residence is 44 percent in 1993 and remains almost the same in 1997. The household size is 4.57 in 1993 and it decreases by 0.1 in 1997 . The proportion of children within households decreases from 0.31 
Table 2: Summary Statistics of the Balanced Panel $(\mathrm{N}=4,852)$

\begin{tabular}{|c|c|c|c|c|}
\hline \multirow[b]{2}{*}{ Variable } & \multicolumn{2}{|c|}{1993} & \multicolumn{2}{|c|}{1997} \\
\hline & Mean & $S . D$. & Mean & S.D. \\
\hline \multicolumn{5}{|l|}{ Demographic Variables } \\
\hline Urban residence (index) & 0.44 & $(0.50)$ & 0.43 & $(0.50)$ \\
\hline Household size & 4.57 & $(2.07)$ & 4.47 & $(2.01)$ \\
\hline Proportion of children in household & 0.31 & $(0.22)$ & 0.28 & $(0.22)$ \\
\hline Proportion of adults in household & 0.69 & $(0.22)$ & 0.72 & $(0.22)$ \\
\hline No. of children & 1.62 & $(1.41)$ & 1.44 & $(1.32)$ \\
\hline No. of adults & 2.95 & $(1.39)$ & 3.03 & $(1.43)$ \\
\hline No. of head's own children & 2.13 & $(1.66)$ & 2.01 & $(1.56)$ \\
\hline No. of head's own sons & 1.11 & $(1.15)$ & 1.05 & $(1.09)$ \\
\hline No. of head's own daughters & 1.02 & $(1.06)$ & 0.96 & $(1.01)$ \\
\hline No. of generations & 2.09 & $(0.58)$ & 2.16 & $(0.60)$ \\
\hline No. of newly born children between waves & & & 0.31 & $(0.55)$ \\
\hline \multicolumn{5}{|l|}{ Household Head Characteristics } \\
\hline Head is female (index) & 0.15 & $(0.36)$ & 0.17 & $(0.38)$ \\
\hline Head's age & 45.57 & $(14.21)$ & 48.38 & $(13.81)$ \\
\hline Head is Muslim (index) & 0.87 & $(0.34)$ & 0.87 & $(0.34)$ \\
\hline Head worked last year (index) & 0.82 & $(0.38)$ & 0.86 & $(0.35)$ \\
\hline Head's years of schooling & 4.74 & $(4.22)$ & 5.34 & $(4.36)$ \\
\hline Head is married (index) & 0.85 & $(0.35)$ & 0.83 & $(0.38)$ \\
\hline Head has a spouse in HH (index) & 0.81 & $(0.39)$ & 0.79 & $(0.41)$ \\
\hline Head is new in the second wave (index) & & & 0.04 & $(0.19)$ \\
\hline \multicolumn{5}{|l|}{ Educational Attainment } \\
\hline No. of adult men with more than primary education & 0.55 & $(0.81)$ & 0.63 & $(0.86)$ \\
\hline No. of adult women with more than primary education & 0.43 & $(0.72)$ & 0.53 & $(0.79)$ \\
\hline No. of adult men with only primary education & 0.30 & $(0.56)$ & 0.33 & $(0.56)$ \\
\hline No. of adult women with only primary education & 0.29 & $(0.51)$ & 0.34 & $(0.54)$ \\
\hline No. of adult men with less then primary education & 0.57 & $(0.66)$ & 0.47 & $(0.63)$ \\
\hline No. of adult women with less then primary education & 0.82 & $(0.71)$ & 0.72 & $(0.68)$ \\
\hline \multicolumn{5}{|l|}{ Working Status } \\
\hline No. of adult men who worked last year & 1.01 & $(0.70)$ & 1.06 & $(0.67)$ \\
\hline No. of adult women who worked last year & 0.69 & $(0.70)$ & 0.62 & $(0.68)$ \\
\hline No. of male children who worked last year & 0.02 & $(0.16)$ & 0.01 & $(0.09)$ \\
\hline No. of female children who worked last year & 0.02 & $(0.14)$ & 0.00 & $(0.07)$ \\
\hline Household with at least one farmer (index) & 0.42 & $(0.49)$ & 0.37 & $(0.48)$ \\
\hline \multicolumn{5}{|l|}{ Measure of Welfare } \\
\hline Real monthly expenditure per person/100 (1986 Rupiah) & 391.06 & $(324.99)$ & 388.08 & $(308.12)$ \\
\hline Expenditure share of food & 0.61 & $(0.20)$ & 0.67 & $(0.18)$ \\
\hline
\end{tabular}

Notes: i) Data source: IFLS1 (1993) and IFLS2 (1997).

ii) 21 observations are dropped due to missing expenditure share of food.

iii) Primary education (six years of schooling) was compulsory until 1994. Since then, junior high school became mandatory. However, the full enrollment of junior high school has not been achieved.

iv) A child is defined as a household member who is less than 15 years old.

v) The sampling weight is not applied. 
to 0.28 between waves. The average number of newly born children between waves is 0.31 , put differently, 27 percent of the households experienced at least one live birth. Only 15 percent of households are headed by a female, and head's average age is 45.6 years in 1993 and 48.4 in 1997. Islam is the dominant religion, as 87 percent of household heads are Muslim. The proportion of household heads who worked in the previous year increases from 82 percent to 86 percent between waves. The educational attainment of household heads increases from 4.7 years in 1993 to 5.3 years in 1997. The proportion of households with new household heads in the second wave is 4 percent. General educational attainment of household members increases between 1993 and 1997 as can be seen in Table 2. The average number of adult men who worked in the previous year increases by 0.05 , but that for adult women decreases by 0.07 in the second wave. Child labor is not common in the sample. The number of households with at least one farmer decreases from 42 percent in 1993 to 37 percent in 1997. Real monthly expenditure per person is 391 Rupiah in 1993 (in 1986 Rupiah), and it slightly decreases to 388 in 1997 (in 1986 Rupiah). The expenditure share of food is 61 percent in 1993, and it increases to 67 percent in 1997.

\section{Measuring Household Welfare}

The most commonly used measure of welfare is the household expenditure per person. ${ }^{1}$ A critical issue when considering the effect of a new born child on welfare is the definition of the equivalence scale (Lanjouw \& Ravallion 1995). A rigorous approach requires the equivalence scale to be derived from the household demand system. Since our purpose is to examine the relationship between fertility and welfare at a descriptive level, we analyse the sensitivity of our results with respect to two aspects of the equivalence scale: 1) the weight assigned to children relative to adults, and 2) the economy of scale in household consumption. To do so we follow Banks \& Johnson (1994) and specify a simple form of the welfare measure where these these aspects of the equivalence scale are easily incorporated:

$$
W=\frac{H}{(A+\alpha K)^{\theta}},
$$

where $H$ denotes total household expenditure, and $A$ and $K$ stand for the number of adults and the number of children respectively. In equation (1), the weight for a child relative to an adult is $\alpha$, and the economy of scale is reflected through the parameter $\theta$. Both $\alpha$ and $\theta$ take a value between 0 and 1 . Section 4 presents a a sensitivity analysis of our estimates for different values of these parameters.

The second measure of welfare we consider is the ratio of food expenditure to total household expenditure. Engel's law states that the standard of living of household members is inversely related to the food share of expenditures or the Engel coefficient. The food share of expenditure does not require an assumption on equivalence scale, and can be regarded as a qualitative measure of welfare. However, the result should be interpreted with a caution because, as Deaton \& Muellbauer (1986) showed, estimating the effect of a child on household welfare using food share of expenditure will overestimate the true effect given the assumption that a child's consumption consists of more food than an adult's and that food is a necessity.

\footnotetext{
${ }^{1}$ Consumption expenditure include expenditures on food, non-food and education. The questionnaire asks food expenditure in the past week, non-food expenditure in the past month (for the non-durable) or in the past year (for the durable), and educational expenditure in the past year.
} 


\section{Statistical Methods}

Since giving birth is a choice made by a couple, the estimate of the effect of a newly born child on household welfare is likely to be biased by the correlation between fertility and household welfare due to unobservable characteristics. In order to address this issue, we take the following linear reduced-form specification for household welfare.

$$
Y_{i, t}=\alpha X_{i, t}+\beta D_{i, t}+\varepsilon_{i, t}
$$

The outcome of interest denoted by $Y_{i, t}$ is a measure of household welfare of household $i$ at time $t$, and the fertility variable, $D_{i, t}$, indicates whether a household $i$ experiences a birth at time $t$. A set of characteristics of household $i$ at time $t$ that affect the household welfare is represented by $X_{i, t}$. The error term, $\varepsilon_{i, t}$ denotes unobservable characteristics in welfare measure of household $i$ at time $t$. It is assumed that $E\left(\varepsilon_{i, t} \mid X_{i, t}\right)=0$ for all $i$ and $t$. The estimate of $\beta$ in equation (2) is biased by the correlation between $\varepsilon_{i, t}$ and $D_{i, t}$, which is called selection bias.

$$
E\left(\varepsilon_{i, t} \mid D_{i, t}, X_{i, t}\right) \neq 0
$$

In order to discuss the nature of the selection issue, the birth outcome is described as an index function as follows.

$$
\begin{aligned}
& D_{i, t}=1 \text { iff } \gamma Z_{i, t}+v_{i, t}>0 \\
& D_{i, t}=0 \text { otherwise. }
\end{aligned}
$$

A set of variables that affect the realization of fertility at time $t$ is denoted by $Z_{i, t}$, and an unobservable characteristic of a household $i$ at time $t$ is represented by $v_{i, t}$. We assume that $v_{i, t}$ is distributed independently of $Z_{i}$. As Heckman \& Hotz (1989) discussed it, there are two kinds of selection problems. One is the selection on observables, which can be described as follows.

$$
\begin{aligned}
& E\left(\varepsilon_{i, t} \mid D_{i, t}, X_{i, t}, Z_{i, t}\right) \neq 0 \\
& E\left(\varepsilon_{i, t} \mid D_{i, t}, X_{i, t}, Z_{i, t}\right)=E\left(\varepsilon_{i, t} \mid X_{i, t}, Z_{i, t}\right)
\end{aligned}
$$

In this situation, the problem is solved by controlling for the observed variables in the fertility equation $\left(Z_{i, t}\right)$. Matching methods produce a consistent estimate of $\beta$ in (2) by controlling for the observed variables in equation (4) nonparametrically.

The other kind of problem is selection on unobservables, which is not solved by controlling for the observable characteristics.

$$
\begin{aligned}
& E\left(\varepsilon_{i, t} \mid D_{i, t}, X_{i, t}, Z_{i, t}\right) \neq 0 \\
& E\left(\varepsilon_{i, t} \mid D_{i, t}, X_{i, t}, Z_{i, t}\right) \neq E\left(\varepsilon_{i, t} \mid X_{i, t}, Z_{i, t}\right)
\end{aligned}
$$

For instance, more fecund women may prefer to invest less in their human capital or alternatively may not be able to invest as much as they would like because they have to allocate more energy or resources to contraception for a given desired level of fertility. In both cases, more fecund women accumulate less human capital, consequently, earn less, and have a lower welfare.

If more fecund women accumulate human capital less either by investing less or by putting more efforts on contraception than less fecund women, then they earn less and have a lower welfare. Matching methods are vulnerable to this possibility, but we believe this is a relatively minor issue in Indonesian context because the decision of schooling seems to be made before 
marriage given the average years of schooling of 5 years and the average age at marriage of 18 years.

To estimate the causal effect of fertility on poverty we apply a matching approach based on the treatment effects literature following the counterfactual model of causal inference. This approach is based on the intuitively attractive idea of contrasting the outcomes of a treatment group $Y_{1}$ with the outcomes of a 'comparable' control group $Y_{0}$. Differences in the outcomes between the two groups are attributed to the treatment $D .^{2}$

The method is based on the identifying assumption that, conditional on $X$, the outcome (here: the poverty transition) of the control group $Y_{0}$ is independent of the treatment $D$ (here: the birth of a child). Using the notation of Dawid (1979), the assumption of strongly ignorable treatment assignment

$$
Y_{0} \Perp D \mid X,
$$

is sufficient to identify the mean effect of treatment on the treated (Rosenbaum \& Rubin 1983):

$$
E\left(Y_{1}-Y_{0} \mid D=1\right)=E\left(Y_{1} \mid D=1\right)-E\left(Y_{0} \mid D=0\right) .
$$

Assumption (7) produces a comparison group that resembles the control group of an experiment in one key aspect: conditional on $X$, the distribution of $Y_{0}$ given $D=1$ is the same as the distribution of $Y_{0}$ given $D=0$ :

$$
E\left(Y_{0} \mid X, D=1\right)=E\left(Y_{0} \mid X, D=0\right)=E\left(Y_{0} \mid X\right)
$$

For estimating the mean effect of treatment on the treated, many matching estimators have been proposed that exploit (7) or its implication (9) for alternative matching methods. For all matching methods, the average treatment effect for the treated (8) can be written as (Heckman et al. 1998):

$$
E\left(Y_{1}-Y_{0} \mid D=1\right)=\sum_{i \in T} w_{i}\left[Y_{1 i}-\sum_{j \in C} W_{i, j} Y_{0 j}\right]
$$

that is, the average (weighted by $w_{i}$ ) of the differences between the events $Y_{1 i}$ of the treatment group $T$ and the events $Y_{0 j}$ of the control group $C$ weighted by $W_{i, j}$. The different matching algorithms differ in the construction of the comparison weights $W_{i, j}$.

Traditional matching methods pair non-treated with treated persons that are 'close' in terms of $X$ using different metrics, e.g. caliper matching of different widths, Mahlanobis distance matching, or Kernel-based matching. In practice (i.e. with samples of typical size) it is often difficult to match on high dimensional $X$. Instead it is easier to do the matching based on individuals' probability of treatment, or in other words the propensity score (Rosenbaum \& Rubin 1983). We define $P(X)$ as the propensity score, with $P(X)=P(T=1 \mid X)$. If the balancing property

$$
D \Perp X \mid P(X)
$$

is satisfied, i.e. $X$ and $D$ are independent conditional on $P(X)$, observations with the same propensity score must have the same distribution of observable and unobservable characteristics independent of treatment status. In other words, for a given propensity score, exposure

\footnotetext{
${ }^{2}$ Matching methods for estimating causal effects have several advantages. First, they make no assumptions about the functional form of the dependence between the outcome of interest and the control variables $X$. Second, matching insures that the $X \mathrm{~s}$ of interest in the treatment group are similar to those in the control group and, thus, prevents from comparing units that are dissimilar. Third, since fewer parameters are estimated than in a traditional regression model, matching may be more efficient which can be important with small samples.
} 
to treatment is random. A theorem of Rosenbaum \& Rubin (1983) demonstrates that if (7) is satisfied, then

$$
Y_{0} \Perp D \mid P(X),
$$

provided $0<P(X)<1$, so that there is a positive probability that the events $D=1$ and $D=0$ occur. This insight shows that matching can be performed on $P(X)$ alone, provided that the balancing property (11) holds.

Propensity scores are implemented in the matching techniques by defining the closeness of propensity scores and the control variable $X$ in different ways. Since estimates are sometimes sensitive to the choice of matching technique, we implement several approaches. In particular we apply Nearest Neighbor matching, Radius matching, Kernel matching, and Stratification matching based on the propensity score (Becker \& Ichino 2002). With nearest neighbor matching, each member of the treatment group is matched to a non-treated unit using the closest propensity score. With radius matching, the treated units are only matched with non-treated units within a pre-specified range around their propensity scores. With kernel matching, the propensity score of each treated unit is matched with the kernel weighted average outcome of all non-treated units. Finally, with stratification matching, the range of variation of the propensity score is divided into intervals such that within each interval treated and control units have on average the same propensity score.

\section{$5 \quad$ Household Consumption Expenditure and Fertility}

This section presents our estimates of the effect of new born child on household welfare using the average treatment effect model. The treatment in this case is to have an additional child born between two waves, and the various welfare measures are 1) household consumption expenditure, with different values of the parameters of the equivalence scale, and 2) the share of food expenditure in total expenditure.

Table 3 presents the result of estimating a probit model for having a child between 1993 and 1997 with a set of variables satisfying the balancing property. Because Indonesia exhibits a huge geographical diversity associated with different socio-economic conditions, we conduct the analysis for the rural and urban sample separately. The result of the estimation for the total sample in column (1) of Table 3 shows that none of the demographic variables constitutes a significant predictor for the fertility decision except the number of generations in a household, which has a positive impact on the probability of experiencing a birth between both waves. Most coefficients on the household head's characteristics are significant. Age, working status in the previous year, and educational attainment of the head have a negative impact on the probability of having a new birth, whereas Muslim households tend to have a newly born child significantly more than households with other religion. The impact of sex of household head is not significant. Among variables of educational attainment of household members, only the number of adult women with more than compulsory education (primary education) has a significant coefficient, which is positive. On the other hand, among variables of working status of household members, only the number of adult men who worked in the previous year has a significant impact, which is positive - and can be interpreted as an income effect. Column (2) and column (3) of Table 3 show that most estimates from the rural and urban sample are similar to those from the total sample in terms of sign and magnitude except for two variables. One is the number of children that has a significant and positive impact on the likelihood of a new birth in the rural sample, but not in the urban sample. The other is the number of adult women with more than compulsory education that loses significance in the rural and urban sample. 
Table 3: Probit Estimation of Having a New Child Between 1993 and 1997

\begin{tabular}{|c|c|c|c|c|}
\hline & & $\begin{array}{c}(1) \\
\text { Total }\end{array}$ & $\begin{array}{c}(2) \\
\text { Rural }\end{array}$ & $\begin{array}{c}(3) \\
\text { Urban }\end{array}$ \\
\hline \multirow{6}{*}{$\begin{array}{l}\text { Demographic } \\
\text { Variables } \\
\text { in } 1993\end{array}$} & Urban & $\begin{array}{c}-0.041 \\
(0.050)\end{array}$ & - & - \\
\hline & No. of children & $\begin{array}{c}0.021 \\
(0.029)\end{array}$ & $\begin{array}{l}0.101 * * \\
(0.036)\end{array}$ & $\begin{array}{c}-0.019 \\
(0.042)\end{array}$ \\
\hline & No. of head's own children & $\begin{array}{c}-0.049 \\
(0.031)\end{array}$ & $\begin{array}{c}-0.077 \\
(0.041)\end{array}$ & $\begin{array}{c}-0.062 \\
(0.045)\end{array}$ \\
\hline & No. of head's own son & $\begin{array}{c}-0.018 \\
(0.031)\end{array}$ & $\begin{array}{c}-0.028 \\
(0.041)\end{array}$ & $\begin{array}{c}-0.008 \\
(0.047)\end{array}$ \\
\hline & No. of adults & $\begin{array}{c}-0.065 \\
(0.046)\end{array}$ & $\begin{array}{c}0.017 \\
(0.056)\end{array}$ & $\begin{array}{c}-0.054 \\
(0.072)\end{array}$ \\
\hline & No. of generations & $\begin{array}{l}0.197 * * \\
(0.051)\end{array}$ & - & $\begin{array}{c}0.198 * \\
(0.077)\end{array}$ \\
\hline \multirow{5}{*}{$\begin{array}{l}\text { Household Head } \\
\text { Characteristics } \\
\text { in } 1993\end{array}$} & Head's age & $\begin{array}{c}-0.023 * * \\
(0.002)\end{array}$ & $\begin{array}{c}-0.023 * * \\
(0.002)\end{array}$ & $\begin{array}{c}-0.024 * * \\
(0.003)\end{array}$ \\
\hline & Head being Muslim & $\begin{array}{l}0.301 * * \\
(0.068)\end{array}$ & $\begin{array}{l}0.280 * * \\
(0.088)\end{array}$ & $\begin{array}{l}0.344 * * \\
(0.108)\end{array}$ \\
\hline & Head worked last year & $\begin{array}{c}-0.296 * * \\
(0.069)\end{array}$ & $\begin{array}{c}-0.334 * * \\
(0.099)\end{array}$ & $\begin{array}{c}-0.212 * \\
(0.101)\end{array}$ \\
\hline & Head's years of schooling & $\begin{array}{r}-0.020 * \\
(0.008)\end{array}$ & $\begin{array}{r}-0.013 \\
(0.012)\end{array}$ & $\begin{array}{c}-0.020 \\
(0.011)\end{array}$ \\
\hline & Head's sex & $\begin{array}{c}-0.147 \\
(0.076)\end{array}$ & $\begin{array}{c}-0.103 \\
(0.103)\end{array}$ & - \\
\hline \multirow{5}{*}{$\begin{array}{l}\text { Educational } \\
\text { Attainment } \\
\text { in } 1993\end{array}$} & No. of adult men with more than compulsory education & $\begin{array}{c}-0.001 \\
(0.063)\end{array}$ & $\begin{array}{c}-0.049 \\
(0.090)\end{array}$ & $\begin{array}{c}0.014 \\
(0.092)\end{array}$ \\
\hline & No. of adult women with more than compulsory education & $\begin{array}{l}0.131 * * \\
(0.047)\end{array}$ & $\begin{array}{c}0.139 \\
(0.072)\end{array}$ & $\begin{array}{c}0.126 \\
(0.066)\end{array}$ \\
\hline & No. of adult men with only compulsory education & $\begin{array}{c}-0.016 \\
(0.072)\end{array}$ & $\begin{array}{c}-0.029 \\
(0.097)\end{array}$ & $\begin{array}{c}-0.045 \\
(0.108)\end{array}$ \\
\hline & No. of adult women with only compulsory education & $\begin{array}{c}0.081 \\
(0.047)\end{array}$ & $\begin{array}{c}0.048 \\
(0.064)\end{array}$ & $\begin{array}{c}0.106 \\
(0.070)\end{array}$ \\
\hline & No. of adult men with less then compulsory education & $\begin{array}{c}-0.061 \\
(0.078)\end{array}$ & $\begin{array}{r}-0.137 \\
(0.105)\end{array}$ & $\begin{array}{c}0.054 \\
(0.111)\end{array}$ \\
\hline \multirow[t]{8}{*}{$\begin{array}{l}\text { Working Status } \\
\text { in } 1993\end{array}$} & No. of adult men who worked last year & $\begin{array}{l}0.233 * * \\
(0.051)\end{array}$ & $\begin{array}{l}0.239 * * \\
(0.072)\end{array}$ & $\begin{array}{l}0.223 * * \\
(0.072)\end{array}$ \\
\hline & No. of adult women who worked last year & - & $\begin{array}{c}0.026 \\
(0.048)\end{array}$ & $\begin{array}{c}-0.045 \\
(0.050)\end{array}$ \\
\hline & No. of male children who worked last year & $\begin{array}{c}-0.155 \\
(0.144)\end{array}$ & $\begin{array}{c}-0.143 \\
(0.188)\end{array}$ & $\begin{array}{c}-0.112 \\
(0.229)\end{array}$ \\
\hline & No. of female children who worked last year & $\begin{array}{c}-0.222 \\
(0.159)\end{array}$ & $\begin{array}{c}-0.297 \\
(0.222)\end{array}$ & $\begin{array}{c}-0.113 \\
(0.231)\end{array}$ \\
\hline & Any member worked as a farmer last year & $\begin{array}{c}0.059 \\
(0.049)\end{array}$ & $\begin{array}{c}0.086 \\
(0.059)\end{array}$ & $\begin{array}{c}-0.032 \\
(0.093)\end{array}$ \\
\hline & Constant & $\begin{array}{c}0.013 \\
(0.155)\end{array}$ & $\begin{array}{c}0.171 \\
(0.192)\end{array}$ & $\begin{array}{c}-0.071 \\
(0.234)\end{array}$ \\
\hline & Observations & 4,694 & 2,652 & 2,042 \\
\hline & Balancing Property & Satisfied & Satisfied & Satisfied \\
\hline
\end{tabular}

Notes: i) Standard errors are in parentheses.

ii) * significant at $5 \%$; ${ }^{*}$ significant at $1 \%$.

iii) 179 households with more than one newborn child were dropped. 
Table 4: Fertility and Household Expenditure Per Person (Propensity Score Matching Method)

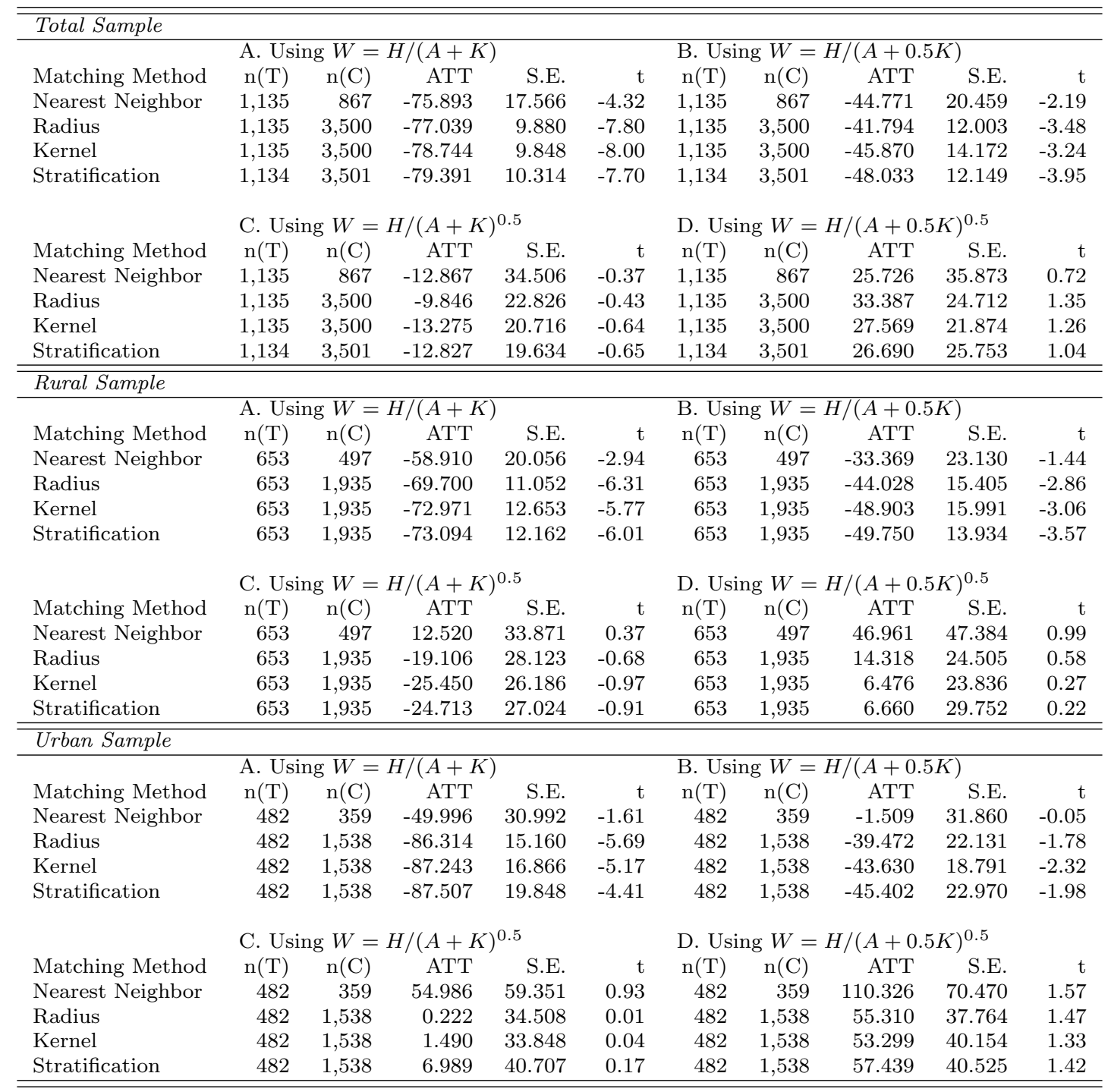

Notes: i) The dependent variable is the difference in real expenditure per person.

ii) Standard errors (S.E.) are computed using bootrap.

iii) 179 households with more than one newborn child were dropped.

iv) Treatment is to have a newly born child between 1993 and 1997.

v) $n(T)$ and $n(C)$ denote the size of treatment group and controlled group, respectively.

vi) ATT denotes the average treatment effect of the treated. 
Table 4 presents the effect of a newly born child on expenditure per person in a household using the matching method described in Section 4 for the whole sample as well as the rural and urban sample separately. The treatment is the event of giving birth to one child between two waves, and the outcome is the difference in real expenditure per person. ${ }^{3}$ The balancing property is satisfied for the set of demographic and socio-economic variables presented in Table 3. When expenditure per person is calculated in a conventional way as in panel A, a newly born child has a significant and negative impact on expenditure per person. A child is defined as a household member of age below fifteen. When a child is counted as a half of an adult as in panel B, the impact decreases by 40 percent and it is still significant. On the other hand, panel $\mathrm{C}$ shows the result with size elasticity 0.5 . Size elasticity of $\theta$ refers to the case where the level of consumption required to keep the members of household of size $n$ as well off as a single adult is equivalent to $n^{\theta}$ times that of a single person. When size elasticity is set to 0.5 , the effect of a newly born child on expenditure per person becomes insignificant although it is still negative. When both relative weight of a child and size elasticity are adopted as in panel D, the effect becomes positive and insignificant. Given the huge geographical diversity in Indonesia, one might expect a systematic difference between rural and urban samples due to the differences in relative prices or in the child care cost. According to Table 4, given an equivalence scale and a matching method, the average treatment effects in the urban sample tend to be larger than the counterparts in the rural sample, but the patterns of estimates with different equivalence scales samples are found to be similar to that from the total sample. ${ }^{4}$

In summary, our results in Table 4 indicate that the negative relationship between a newly born child and household expenditure per person is highly sensitive to both the choice of a weight of a child relative to an adult and size elasticity. As can be expected from panel $\mathrm{C}$ in Table 4, for the range of size elasticity estimated in Table 6 (Appendix A) there exists a positive and significant relationship between newly born child and expenditure per person in IFLS ${ }^{5}$.

As a next step we estimate the effect of a newly-born child on food share of household expenditure using propensity score matching method. The balancing property is satisfied and the first stage probit estimation is reported in Appendix A. The results are presented in Table 5. Four different matching methods produce the same result that the estimates of the average treatment effect are close to zero and imprecisely estimated. As discussed in Section 3, the estimates will overestimate the true effect if a child's consumption consists of more food than that of an adult. This implies, in turn, that the estimates in Table 5 can be considered as an upper bound. Therefore, when a food share of expenditure is used as a measure of welfare, the result provides no evidence that a newly born child lowers the welfare of household members. It is possible that the effect of an additional child on the food share of expenditure depends on the demographic composition of the household. Nevertheless, the food share of expenditure can be considered as a qualitative measure of household wellbeing.

\footnotetext{
${ }^{3}$ If a birth took place near the time of survey, then the consumption expenditure might be measured before the birth (therefore, measuring outcome before the treatment). To address the issue, we conducted the following analysis dropping from the treatment group the households whose newly born child is zero years old in 1997. The qualitative result remains the same as presented in the paper.

${ }^{4}$ One observation is notable. The average treatment effect estimated using nearest neighbor matching method tends to be greater than the other estimates in both subsamples. Further, the estimates seem to be ranked in the order of nearest neighbor matching, radius matching, kernel matching, and stratification matching. However, to our knowledge, there is no study that verifies a systematic difference in the magnitudes of the average treatment effect from different matching methods.

${ }^{5}$ The result is not shown, but it can be inferred from Table 4 which suggests that the effect of newly born child becomes insignificant with size elasticity of 1/2 (Panel C for each sample).
} 
Table 5: Effect of Newly Born Child on Engel Coefficient (Propensity Score Matching Method)

\begin{tabular}{lrrrrr}
\hline \hline Matching Method & $\mathrm{n}(\mathrm{T})$ & $\mathrm{n}(\mathrm{C})$ & ATT & S.E. & $\mathrm{t}$ \\
Nearest Neighbor & 1,132 & 826 & 0.003 & 0.012 & 0.28 \\
Radius & 1,132 & 3,481 & -0.004 & 0.008 & -0.45 \\
Kernel & 1,132 & 3,481 & 0.002 & 0.008 & 0.26 \\
Stratification & 1,131 & 3,482 & 0.003 & 0.007 & 0.50 \\
\hline \hline
\end{tabular}

Notes: 1) The dependent variable is the difference in household food share of expenditure.

2) Standard errors (S.E.) are computed using bootrap.

3) 179 households with more than one newborn child were dropped.

4) Treatment is to have a newly born child between 1993 and 1997.

5) $n(T)$ and $n(C)$ denote the size of treatment group and controlled group, respectively.

6) ATT denotes the average treatment effect of the treated.

\section{Conclusion}

This paper describes the causal effect of fertility on household wellbeing using two measures. When consumption expenditure per person is used as a measure of welfare, the effect of a newly born child on household welfare is extremely sensitive to the choice of equivalence scale. Following Lanjouw \& Ravallion (1995), the implied size elasticity from Engel curve estimation in the IFLS is in the range from 0.14 to 0.28 . When this range is assumed for the equivalence scale, the effect of a newly born child on household expenditure per person is positive and significant. However, the interpretation should be made with a caution because Engel curve estimation involves some restrictions on household consumption choice. When the food share of household expenditure is used as a measure of household welfare, a newly born child does not lower the household welfare. Therefore, the analysis so far suggests that there is no decisive evidence for the negative effect of fertility on household welfare in the short run.

There are a couple of directions considered for future research. First, we plan to extend this study by using other measures of household welfare including body mass index. Secondly, given the difficulty of having a measure of welfare, it will be interesting to examine the impact of a newly born child on labor productivity of adults in a household. Lastly, because poverty is measured as a aggregate variable in a household in this study, it is not clear how fertility is going to affect total household income. Therefore, estimating the effect of fertility on family labor supply or earnings of household members in a structural model will be a fruitful way of investigating the causal relationship between fertility and household welfare. 


\section{Bibliography}

Angrist, J. \& Evans, W. 1998, 'Children and Their Parents' Labor Supply: Evidence from Exogenous Variation in Family Size', The American Economic Review, vol. 88(3), pp. 450-477.

Banks, J. \& Johnson, P. 1994, 'Equivalence Scale Relativities Revisited', Economic Journal, vol. 104, no. 425 , pp. $883-890$.

Becker, S.O. \& Ichino, A. 2002, 'Estimation of Average Treatment Effects Based on Propensity Scores', The Stata Journal, vol. 2, pp. 358-377.

Birdsall, N., Kelley, A.C. \& Sinding, S.W. 2001, 'Population Matters: Demographic Change, Economic Growth, and Poverty in the Developing World', Oxford: Oxford University Press.

Dawid, A.P. 1979, 'Conditional Independence in Statistical Theory', Journal of the Royal Statistical Society, Series B, vol. 41, pp. 1-31.

Deaton, A.S. \& Muellbauer, J. 1986, 'On Measuring Child Costs: With Applications to Poor Countries', Journal of Political Economy, vol. 94(4), pp. 720-744.

Dercon, S. \& Krishnan, P. 2000, 'Vulnerability, Seasonality and Poverty in Ethiopia', Journal of Development Studies, vol. 36(6), pp. 25-53.

Eastwood, R. \& Lipton, M. 1999, 'The Impact of Changes in Human Fertility on Poverty', Journal of Development Studies, vol. 36(1), pp. 1-30.

Frankenberg, E. \& Karoly, L. 1995, 'The 1993 Indonesian Family Life Survey: Overview and Field Report', November, RAND, Santa Monica, CA.

Frankenberg, E. \& Thomas, D. 2000, 'The Indonesia Family Life Survey (IFLS): Study Design and Results from Waves 1 and 2', March 2000. RAND, Santa Monica, CA. DRU-2238/1-NIA/NICHD.

Heckman, J.J., Ichomura, H. \& Todd, P.E. 1998, 'Matching as an Econometric Evaluation Estimator', Review of Economic Studies, vol. 65, pp. 261-294.

Koulovatianos, C., Schröder, C. \& Schmidt, U. 2005, 'On the Income Dependence of Equivalence Scales', Journal of Public Economics, vol. 89, pp. 967-996.

Lanjouw, P. \& Ravallion, M. 1995, 'Poverty and Household Size', Economic Journal, vol. 105, no. 433, pp. $1415-1434$

Lipton, M. 1998, 'Successes in Anti Poverty', International Labor Organization, Geneva.

Livi-Bacci, M. \& de Santis, G. 1998, 'Population and Poverty in Developing World', Oxford: Clarendon Press.

Mankiw, N.G., Romer, D. \& Weil, D.N. 1992, 'A Contribution to the Empirics of Economic Growth', The Quarterly Journal of Economics, vol. 107(2), pp. 407-437.

Mason, A., \& Lee, S-H. 2004, 'The Demographic Dividend and Poverty Reduction', Seminar on the Relevance of Population Aspects for the Achievement of the Millennium Development Goals. $\mathrm{UN} / \mathrm{POP} / \mathrm{PD} / 2004 / 19$.

Mattei, A. 2004, 'Estimating Causal Effects in Experimental and Observational Studies Suffering from Missing Data', Ph.D Thesis in Applied Statistics, Dipartimento di Statistica "G. Parenti", Universit degli Studidi Firenze (Italy). 
Mcculloch, N. \& Baulch, B. 2000, 'Stimulating the impact of policy upon chronic and transitory poverty in rural Pakistan', Journal of Development Studies, vol. 36(6), pp. 100-130.

McNicoll, G. 1997, 'Population and poverty: A review and restatement', Policy Research Division Working Paper no. 105. New York: Population Council.

Merrick, T. 2001, 'Population and Poverty in Households: A Review of Reviews', in: Birdsall, N., Kelley, A.C. and S.W. Sinding (eds.) Population Matters: Demographic Change, Economic Growth, and Poverty in the Developing World, Oxford: Oxford University Press.

Ravallion, M. 1996, 'Issues in measuring and modelling poverty', The Economic Journal, vol.106, no.438, pp. $1328-1343$.

Rosenbaum, P.T. \& Donald B. Rubin 1983, 'The Central Role of Propensity Score in Observational Studies', Biometrika, vol. 70, pp. 41-55.

Rosenzweig, M. \& Schultz, T.P. 1985, 'The Demand for and Supply of Births: Fertility and its Life Cycle Consequences', The American Economic Review, vol. 75(5), pp. 992-1015.

Rosenzweig, M. \& Wolpin, K. 1980, 'Testing the Quantity-Quality Fertility Model: The Use of Twins as a Natural Experiment', Econometrica, vol. 48(1), pp. 227-240.

Rosenzweig, M. \& Wolpin, K. 2000, 'Natural "Natural Experiments" in Economics', Journal of Economic Literature, vol. 38(4), pp. 827-874.

Rubin, D.B. \& Thomas, N. 1996, 'Matching Using Estimated Propensity Scores: Relating Theory to Practice', Biometrics, vol. 52, pp. 249-261.

Schoumaker, B. \& Tabutin, D. 1999, 'Relationship between poverty and fertility in Southern countries. Knowledge, methodology and cases', WP.2, Department of science of population and development, Universit catholique de Louvain.

UN, Department of International Economic and Social Affairs 2000, World population prospects as assessed in 2000, vol. 1, New York, the United States, United Nations.

Vuri, D. 2003, 'Propensity Score Estimates of the Effects of Fertility on Marital Dissolution', European University Institute Economics Working Papers no. ECO2003/04. 


\section{Appendix}

\section{A Estimating Size Elasticity}

Following Lanjouw and Ravallion (1995), we estimate the equivalence scale implied by our data of Indonesia. In order to keep a linear specification in the estimation, we assume that the welfare of any individual in a household is $x / n^{\theta}(0<\theta<1)$, where $x$ is total household expenditure, and $n$ denotes the number of household members. In other words, the weight on a child relative to an adult is fixed at one (i.e. $\alpha=1$ in (1)), and $n^{\theta}$ can be considered as the equivalent number of single individuals. Then, the welfare of household members has an elasticity of $\theta$ with respect to the size of the household. We call it size elasticity following Lanjouw and Ravallion (1995). Although the specification is restricted, the purpose of this exercise is to find a range of one-dimensional equivalence scales implied by the data in order to assess the relationship between fertility and household welfare measured by consumption expenditure.

We estimate size elasticity by regressing the food share on the log expenditure per person and a set of demographic variables. In order to control for relative prices across regions, the community fixed effect is captured by having dummy variables for each community. The basic specification is the following.

$$
\begin{aligned}
\varpi_{i, j} & =\alpha+\beta \ln \left(x_{i, j} / n_{i, j}^{\theta}\right)+X_{i, j}^{\prime} \gamma+\mu_{j}+\varepsilon_{i, j} \\
& =\alpha+\beta \ln \left(x_{i, j}\right)-\beta \theta \ln \left(n_{i, j}\right)+X_{i, j}^{\prime} \gamma+\mu_{j}+\varepsilon_{i, j}
\end{aligned}
$$

where $\varpi_{i, j}$ is the food share of household $i$ in village $j, x_{i, j}$ is total household expenditure, $n_{i, j}$ denotes the number of household members, $\theta$ is the size elasticity, $X_{i, j}$ is a set of demographic variables, $\mu_{j}$ is community specific characteristics including prices in village $j, \varepsilon_{i, j}$ represents a residual, and coefficients are represented by $\alpha, \beta$ and $\gamma$. The estimate of size elasticity, $\theta$, is obtained by taking the ratio of the coefficient on log of household size to that of log of household expenditure in equation (13).

Table 6 shows the estimate of size elasticity from cross section and differenced equation estimation following Lanjouw and Ravallion (1995). Using a similar specification as in Lanjouw and Ravallion (1995), column (1), (3), and (5) indicate that the estimated size elasticity ranges from 0.11 to 0.28 . These estimates are much lower than their estimate (0.6). 
Table 6: Estimation of the Size Elasticity using Engel's Method

\begin{tabular}{|c|c|c|c|c|c|c|}
\hline Dependent variable & $\begin{array}{c}(1) \\
\text { Comm FE } \\
\text { Food share }\end{array}$ & $\begin{array}{l}(2) \\
\text { Comm FE } \\
\text { e in } 1993\end{array}$ & $\begin{array}{c}(3) \\
\text { Comm FE } \\
\text { Food shar }\end{array}$ & $\begin{array}{l}\text { (4) } \\
\text { Comm FE } \\
\text { e in } 1997\end{array}$ & $\begin{array}{c}(5) \\
\text { HH FE } \\
\Delta \text { Food }\end{array}$ & \begin{tabular}{l}
\multicolumn{1}{c}{$(6)$} \\
HH FE \\
share
\end{tabular} \\
\hline $\log$ total expenditure $(\beta)$ & $\begin{array}{c}-0.119 * * \\
(0.004)\end{array}$ & - & $\begin{array}{c}-0.089 * * \\
(0.004)\end{array}$ & - & $\begin{array}{c}-0.083 * * \\
(0.005)\end{array}$ & - \\
\hline $\log$ hh size $(\beta \theta)$ & $\begin{array}{c}0.034 * \\
(0.015)\end{array}$ & - & $\begin{array}{c}-0.010 \\
(0.014)\end{array}$ & - & $\begin{array}{c}0.019 \\
(0.020)\end{array}$ & - \\
\hline log expenditure per person & - & $\begin{array}{c}-0.119 * * \\
(0.004)\end{array}$ & - & $\begin{array}{c}-0.089 * * \\
(0.004)\end{array}$ & - & $\begin{array}{c}-0.082 * * \\
(0.005)\end{array}$ \\
\hline no. of adults & $\begin{array}{c}-0.008 * \\
(0.004)\end{array}$ & $\begin{array}{c}-0.027 * * \\
(0.002)\end{array}$ & $\begin{array}{c}0.007 \\
(0.004)\end{array}$ & $\begin{array}{c}-0.017 * * \\
(0.002)\end{array}$ & $\begin{array}{c}-0.005 \\
(0.005)\end{array}$ & $\begin{array}{c}-0.020 * * \\
(0.003)\end{array}$ \\
\hline no. of children & $\begin{array}{r}-0.006 \\
(0.004)\end{array}$ & $\begin{array}{c}-0.026 * * \\
(0.002)\end{array}$ & $\begin{array}{c}0.004 \\
(0.004)\end{array}$ & $\begin{array}{c}-0.020 * * \\
(0.002)\end{array}$ & $\begin{array}{c}-0.005 \\
(0.005)\end{array}$ & $\begin{array}{c}-0.019 * * \\
(0.003)\end{array}$ \\
\hline Constant & $\begin{array}{l}1.439 * * \\
(0.024)\end{array}$ & $\begin{array}{l}1.407 * * \\
(0.024)\end{array}$ & $\begin{array}{l}1.282 * * \\
(0.026)\end{array}$ & $\begin{array}{l}1.256 * * \\
(0.026)\end{array}$ & $\begin{array}{l}0.056 * * \\
(0.003)\end{array}$ & $\begin{array}{c}0.056 * * \\
(0.003)\end{array}$ \\
\hline Observations & 4,852 & 4,852 & 4,590 & 4,590 & 4,852 & 4,852 \\
\hline No. Communities & 311 & 311 & 310 & 310 & & \\
\hline R-squared & 0.22 & 0.21 & 0.12 & 0.11 & 0.07 & 0.07 \\
\hline Implied Size Elasticity $(\theta)$ & 0.28 & 1.00 & 0.11 & 1.00 & 0.23 & 1.00 \\
\hline
\end{tabular}

Notes: i) Explanatory variables in column (1) - (4) are the values in the year corresponding to the dependent variable.

ii) Explanatory variables in column (5) - (6) are the differences between values in 1993 and 1997.

iii) Standard errors are in parentheses.

iv) * significant at $5 \%$;* significant at $1 \%$.

\section{B The First Stage Estimation for Table 5}

In order to generate the propensity score, we estimate the probability of a household's having a birth between 1993 and 1997 using a probit model. The number of observations is different from the sample used for estimating the effect of newly born child on consumption expenditure, because observations with negative the food food expenditures are dropped. The set of explanatory variable is similar to that in Table 3. It includes demographic variables, household heads' characteristics, educational attainment of household members, working status of adults and total household expenditure. The result, presented in Table 7, is almost identical to that in Table 3. 
Table 7: Probit Estimation of Having a New Child Between 1993 and 1997

\begin{tabular}{|c|c|c|}
\hline & & $(1)$ \\
\hline \multirow{7}{*}{$\begin{array}{l}\text { Demographic } \\
\text { Variables }\end{array}$} & Urban & -0.038 \\
\hline & & $(0.051)$ \\
\hline & No. of children & $\begin{array}{c}0.022 \\
(0.029)\end{array}$ \\
\hline & No. of head's own children & $\begin{array}{c}-0.049 \\
(0.031)\end{array}$ \\
\hline & No. of head's own son & $\begin{array}{c}-0.016 \\
(0.031)\end{array}$ \\
\hline & No. of adults & $\begin{array}{c}-0.062 \\
(0.048)\end{array}$ \\
\hline & No. of generations & $\begin{array}{c}0.197 * * \\
(0.051)\end{array}$ \\
\hline \multirow[t]{5}{*}{$\begin{array}{l}\text { Household Head } \\
\text { Characteristics }\end{array}$} & Head's age & $\begin{array}{c}-0.023 * * \\
(0.002)\end{array}$ \\
\hline & Head being Muslim & $\begin{array}{l}0.295 * * \\
(0.068)\end{array}$ \\
\hline & Head worked last year & $\begin{array}{c}-0.293 * * \\
(0.071)\end{array}$ \\
\hline & Head's years of schooling & $\begin{array}{c}-0.020 * \\
(0.008)\end{array}$ \\
\hline & Head's sex & $\begin{array}{c}-0.148 \\
(0.076)\end{array}$ \\
\hline \multirow[t]{5}{*}{$\begin{array}{l}\text { Educational } \\
\text { Attainment }\end{array}$} & No. of adult men with more than compulsory education & $\begin{array}{c}0.003 \\
(0.065)\end{array}$ \\
\hline & No. of adult women with more than compulsory education & $\begin{array}{l}0.135 * * \\
(0.048)\end{array}$ \\
\hline & No. of adult men with only compulsory education & $\begin{array}{c}-0.014 \\
(0.074)\end{array}$ \\
\hline & No. of adult women with only compulsory education & $\begin{array}{c}0.083 \\
(0.047)\end{array}$ \\
\hline & No. of adult men with less then compulsory education & $\begin{array}{c}-0.057 \\
(0.079)\end{array}$ \\
\hline \multirow[t]{9}{*}{ Working Status } & No. of adult men who worked last year & $\begin{array}{l}0.229 * * \\
(0.051)\end{array}$ \\
\hline & No. of adult women who worked last year & $\begin{array}{c}-0.001 \\
(0.034)\end{array}$ \\
\hline & No. of male children who worked last year & $\begin{array}{c}-0.181 \\
(0.147)\end{array}$ \\
\hline & No. of female children who worked last year & $\begin{array}{c}-0.216 \\
(0.160)\end{array}$ \\
\hline & Any member worked as a farmer last year & $\begin{array}{c}0.056 \\
(0.050)\end{array}$ \\
\hline & Log of household expenditure & $\begin{array}{c}-0.013 \\
(0.032)\end{array}$ \\
\hline & Constant & $\begin{array}{c}0.096 \\
(0.252)\end{array}$ \\
\hline & Observations & 4,673 \\
\hline & Balancing Property & Satisfied \\
\hline
\end{tabular}

Notes: i) Standard errors are in parentheses.

ii) * significant at $5 \%$; $*$ significant at $1 \%$.

iii) Dependent variable is the index for having a newborn child between 1993 and 1997.

iv) A unit of observation is a household.

v) All the explanatory variables denote the values in 1993 .

vi) 179 households with more than one newborn child were dropped. 


\section{VIENNA INSTITUTE OF DEMOGRAPHY}

\section{Working Papers}

Kim, Jungho. Women's Education in the Fertility Transition: The Reversal of the Relationship Between Women's Education and Birth Spacing in Indonesia. VID Working Papers 05/2005. Vienna: Vienna Institute of Demography.

Kim, Jungho. Learning by Doing and Learning from Others in Contraceptive Technology. VID Working Papers 04/2005. Vienna: Vienna Institute of Demography.

Heiland, Frank, Alexia Prskawetz, and Warren C. Sanderson. Do the MoreEducated Prefere Smaller Families? VID Working Papers 03/2005. Vienna: Vienna Institute of Demography.

Henriette Engelhardt und Alexia Prskawetz. Arbeitsmarkt und Demographie. VID Working Papers 02/2005. Vienna: Vienna Institute of Demography.

Sobotka, Tomáš, Maria Winkler-Dworak, Maria Rita Testa, Wolfgang Lutz, Dimiter Philipov, Henriette Engelhardt, and Richard Gisser. Monthly Estimates of the Quantum of Fertility: Towards a Fertility Monitoring System in Austria. VID Working Papers 01/2005. Vienna: Vienna Institute of Demography.

Schwarz, Franz. 2004. Analysis of Inequalities in Waiting Time at the Visit to the Physician using Regression Modeling for Duration Data. VID Working Papers 04/2004. Vienna: Vienna Institute of Demography.

Prskawetz, Alexia, Tomas Kögel, Warren C. Sanderson, and Sergei Scherbov. 2004. The Effects of Age Structure on Economic Growth: An Application of Probabilistic Forecasting to India. VID Working Papers 03/2004. Vienna: Vienna Institute of Demography.

Engelhardt, Henriette. 2004. Fertility Intentions and Preferences: Effects of Structural and Financial Incentives and Constraints in Austria. VID Working Papers 02/2004. Vienna: Vienna Institute of Demography.

Fliegenschnee, Katrin, Anne Goujon, and Wolfgang Lutz. 2004. Neue demographische Szenarien zur Zukunft der Evangelischen Kirche in Österreich. VID Working Papers 01/2004. Vienna: Vienna Institute of Demography. 